\title{
THE EFFECT OF THE MORPHOLOGICAL PROPERTIES OF THE EAR ON THE SUSCEPTIBILITY OF WINTER WHEAT TO SPROUTING IN THE EAR
}

\author{
Eero Varis and Matti Manneri
}

Plant Breeding Institute of Hankkija, Experimental Farm Anttila

Received March, 21, 1963

With the general use of combine harvesting, damage caused by sprouting in the ear has become one of the worst factors deteriorating the quality of bread grain $(21,13,18)$. As the production of domestic bread grain has at the same time increased considerably, sprouting in the ear has become a problem demanding greater attention in variety research $(12,19,20,15,8)$.

Sprouting in the ear of winter wheat has been studied at the Plant Breeding Institute of Hankkija since 1957. The sand bed method developed by HänSEL (10) was adopted as the object was to establish the genetic susceptibility to sprouting in the ear of the plant breeding material without the disturbing influence of various ear types. However, the need soon arose to establish the magnitude of the influence of the type and hairiness of the ear. For the elucidation of this question an experiment was conducted in autumn 1958 which will be discussed below.

\section{Review of the literature}

Domestic studies of sprouting in the ear have been concerned with the differences between varieties, annual variations due to weather conditions and the differences caused by the time of harvesting and handling of grain (cf. above). The effect of sprouting on the quality of wheat has also been considered $(22,23)$.

In Sweden, Nilsson-Ehle (14) had already drawn attention to the differences between varieties, Åkerman (1) had made extensive comparisons between whiteand red-grained wheat, finding the former to sprout more readily. In Central Europe, several investigators have studied the morphological and physiological ripening of cereals, inter-variety differences and suitable laboratory methods of studying sprouting in the ear, and annual variations due to weather conditions $(27,16,5$, $7,17,4,26,6,10,24,25,2)$. 
The significance of the morphological structure of the ear has also been studied by many workers. Prochaska (16) studied the effect of the density, awnedness and hairiness of the ear and of the thickness of the glumes on the water-retaining capacity of the ears, and on the susceptibility to sprouting. He found that the first three properties promote sprouting, while awnedness, especially when combined with a nutant ear, reduces it. Voss (26) did not regard the influence of e.g. awnedness as essential. Some workers in England have discussed the significance of glumes and type of ear in preventing sprouting $(9,25)$.

\section{Material and methods}

The experiment was carried out at the Experimental Farm of the Plant Breeding Institute of Hankkija on September 1-30, 1958. The material consisted of the winter wheat breeding material which included lines differing very greatly both in their genetic susceptibility to sprouting in the ear and in the type of ear. Some foreign varieties were also included in the material. The experiment covered a total of 94 varieties. It was carried out in a greenhouse where the temperature was $15-20^{\circ} \mathrm{C}$ during the day and $10-15^{\circ} \mathrm{C}$ at night.

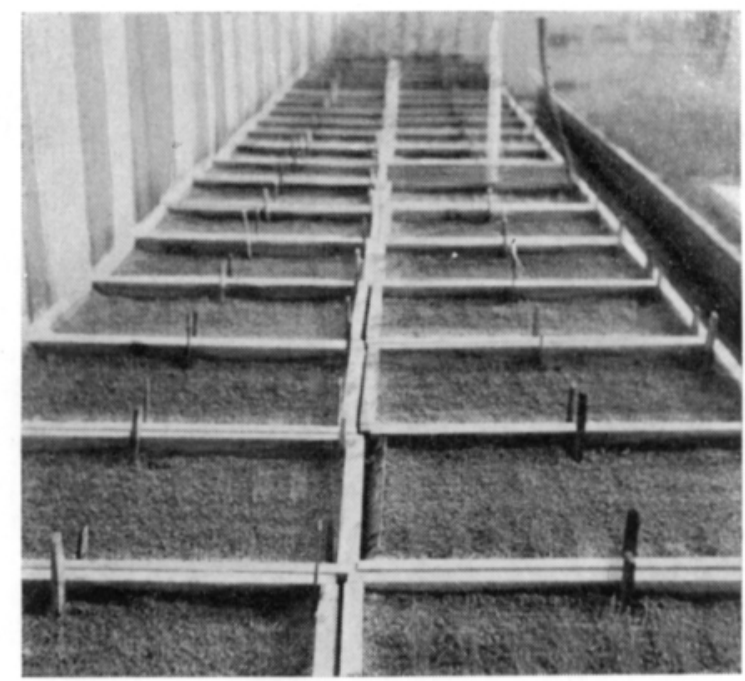

Fig. 1. Sprouting ears in moist sand. Hänsel's sandbed medhod.

Two different methods were used parallelly to ascertain the influence of the ear type:

1. HänSEL's sandbed method was used to find out the genetic susceptibility of the varieties to sprouting in the ear. A $9 \mathrm{~cm}$ thick layer of sand was sifted into wooden boxes measuring $50 \times 30 \times 10 \mathrm{~cm}$ (Fig. 1). The ears were harvested from the experimental field when each variety had reached the stage of yellow ripeness. After counting the number of grains in each ear, a total of 20 ears, in 5-ear series, from 4 different varieties were placed into each box at a depth of c. $2 \mathrm{~cm}$. There 
were three replicates $(3 \times 5$ ears $)$ of each variety. The boxes were watered thoroughly twice a day, at 07.00 and 17.00 hours. The new sprouts coming to the surface were counted every morning, cutting them off with scissors to simplify the counting. The experiment took 13 days for each variety.

2. A modification of Schleip's (17) method was chosen as the other method. The object was to approximate natural conditions and in the following it is called the mature method". The ears, which had c. $30 \mathrm{~cm}$ of straw, were placed upright on a stand of two superimposed perforated hardboards. Plastic covers were used to raise the relative humidity of air (Figs. 2 and 3). Thirty ears of each variety were taken and placed in the stand in groups of $3 \times 10$ ears. The ears were watered in

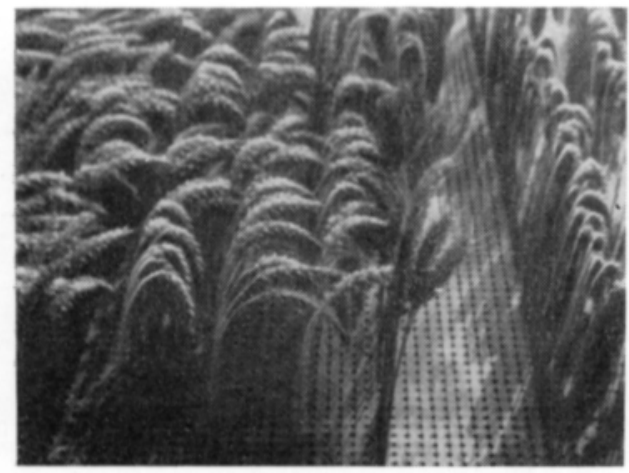

Fig. 2. Sprouting ears in their natural position on the stand of perforated hardboards, nnature methods.

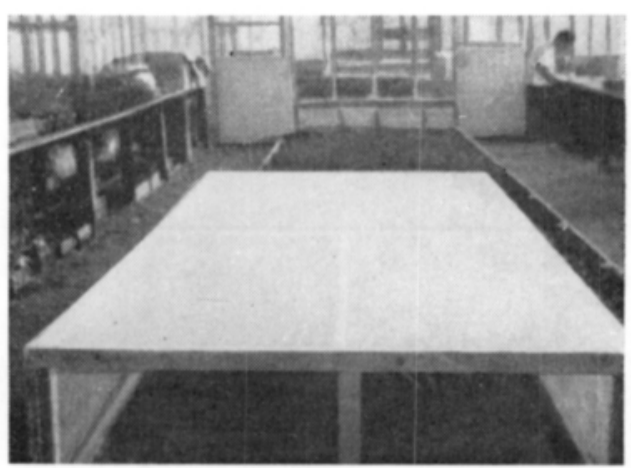

Fig. 3. Plastic cover, snature methods.

the afternoon at 17.00 hours and were then covered by plastic covers for the night. The covers were removed at 07.00 hours and the ears were allowed to dry until watering at 13.00 hours. After watering they were again allowed to dry until 17.00 hours. The progress of sprouting in the ear was studied by harvesting the series 4,8 and 12 days after the beginning of the experiment (I, II and III). The ears were dried and threshed by hand, and the proportion of sprouted grains was determined according to the instructions issued by the State Seed Testing Station (11).

Two minor experiments were conducted in connection with the mature method" to compare the water-retaining capacity of bald and hairy ears. In both these experiments, 2 bald and 2 hairy varieties were placed in the conditions of the nnature method" in groups of $3 \times 5$ ears. The ears were weighed air-dry at the beginning of the experiment, in the mornings after the removal of the covers and in the evenings before the second watering. The experiments were continued for 3 and 4 days, respectively.

\section{Results and discussion}

The experimental material was divided into 4 classes on the basis of the ear type: 1) hairy erect, 2) hairy nutant, 3) bald erect and 4) bald nutant. 
The results are given as the germination percentage of the number of grains in the ears. The statistical significance of the influence of ear type was tested by comparing the results of the two methods (sandbed - nature method) for the following days: 7-I, 10-II and 13-III. The difference of the means was calculated for each day and its significance was studied by the t-test (3). The comparisons mentioned above were used in calculating the correlation coefficients $\mathrm{r}$ in the comparison of the two methods.

The water-retaining capacity of bald and hairy ears was tested statistically by variance analysis (3).

Comparison of the methods. The first point to be clarified was whether the methods used give similar results irrespective of ear type. The correlation cal-

Table 1. Comparison of the sandbed method of HÄNSEL and the mature method.

\begin{tabular}{|c|c|c|c|c|c|c|c|c|c|c|c|c|}
\hline \multirow[t]{2}{*}{ Class } & \multirow[t]{2}{*}{$\begin{array}{l}\text { Number of } \\
\text { varieties }\end{array}$} & \multicolumn{8}{|c|}{ Sandbed } & \multicolumn{3}{|c|}{ Nature method } \\
\hline & & 6 & 7 & 8 & 9 & 10 & 11 & 12 & 13 & I & II & III \\
\hline Slow & 32 & 0 & 0 & 1 & 3 & 7 & 13 & 19 & 29 & 17 & 50 & 70 \\
\hline Medium & 32 & 0 & 1 & 4 & 8 & 15 & 23 & 34 & 48 & 25 & 57 & 80 \\
\hline Rapid & 30 & 1 & 5 & 11 & 20 & 30 & 43 & 53 & 65 & 33 & 69 & 90 \\
\hline
\end{tabular}

Table 2. The effect of the ear type on the sprouting susceptibility.

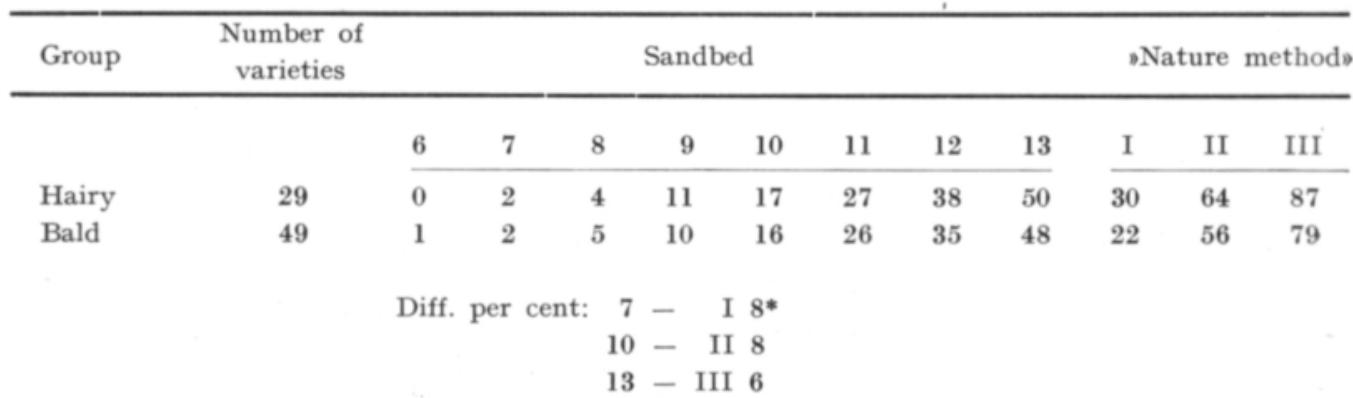

Table 3. The effect of the position of the ear on the sprouting susceptibility.

\begin{tabular}{lccccccccccccccccc}
\hline Group & $\begin{array}{c}\text { Number of } \\
\text { varieties }\end{array}$ & \multicolumn{4}{c}{ Sandbed } & & *Nature method \\
\hline & & 6 & 7 & 8 & 9 & 10 & 11 & 12 & 13 & I & II & III \\
Erect & 27 & 0 & 1 & 4 & 11 & 17 & 27 & 37 & 48 & 32 & 64 & 82 \\
Nutant & 51 & 0 & 2 & 5 & 10 & 16 & 27 & 36 & 49 & 21 & 57 & 82
\end{tabular}

Diff. per cent: $7-$ I $10 * *$

$10-$ II $7(*)$

13 - III 1 
culation gave the coefficients $7-\mathrm{I}+0.57 * * *, 10-\mathrm{II}+0.52 * * *$ and 13 - III + $0.62 * * *$. To illustrate the point, the experimental members of each sub-group were divided into 3 groups: 1) slow, 2) medium and 3) rapid according to the sandbed method. The means obtained and the corresponding mature method» values are given in Table 1.

Both methods gave similar results and, consequently, both can be used to establish the susceptibility of different varieties to sprouting in the ear.

Hairy - bald. To compare the effect of the ear type on the sprouting susceptibility the material was milked" until the genetic susceptibility of each group to sprouting (sandbed) was as close as possible to the mean for the total material.

This was not entirely succesful in the group "bald erect" on account of its smallness. Some idea of the effect of the ear type was obtained by a comparison with the corresponding mature method" values.

Table 2 gives the result obtained. At first, the hairy ears sprouted 8 per cent more profusely than the bald, and the difference was statistically significant. The difference in favour of the bald ears persisted to the end, though it ceased to be statistically significant.

The result supports the conclusions by PROCHASKA (16) and observations that have been made in practice. It suggests that hairy ear types should be avoided, and in fact they have already been abandoned in most countries in breeding work.

Erect - nutant ears. Table 3 shows the difference between erect and nutant ears. Nutant ears were distincly better than erect in the beginning, but the difference levelled itself out towards the end. This difference is obviously due to the fact that the grains are protected in the nutant ear and rain water cannot reach the grains directly. An eréct, often dense ear the glumes of which stick out obviously collects more rain drops between its spikelets than the nutant ear and the glumes and grains thus keep moist longer. Hutchinson et al. (9) studied the role of the position of the ear by germinating the ears of the same varieties erect, drooping and after thinning every other spikelet. The result showed a slight trend in favour of the last two alternatives, but in the author's view the difference lay within the limits of error.

Hairy erect - hairy nutant. Bald erect - bald nutant. Finally, the material was classified into all 4 ear types with the object of ascertaining the behaviour of the different types. The result (Table 4) shows that the different groups sprouted differently, as could be concluded from the previous analyses. Hairy erect ears are poorer than hairy nutant ears, and similarly bald erect ears are more sensitive than bald nutant.

Water-retaining capacity of hairy and bald ears. Table 5 shows the result of the experiment analysing the water-retaining capacity of different types of ear. The water-retaining capacity of hairy ears was greater than that of bald ears for the relative weight increase in experiment I for hairy ears was $14.2-19.4$ per cent and in experiment II 20.1-30.7 per cent greater than for bald ears. ProchaskA (16) studied the same point and found that the weight increase for hairy glumes after soaking in water for ${ }^{-} 24$ hours was 25 per cent greater than the increase for bald ears. 
Table 4. The effect of the ear type on the sprouting susceptibility.

\begin{tabular}{lccccccccccccc}
\hline Group & $\begin{array}{c}\text { Number of } \\
\text { varieties }\end{array}$ & \multicolumn{4}{c}{ Sandbed } & \multicolumn{1}{c}{ Nature method" } \\
\hline & & 6 & 7 & 8 & 9 & 10 & 11 & 12 & 13 & I & II & III \\
Hairy erect & 17 & 0 & 1 & 4 & 9 & 17 & 27 & 38 & 50 & 30 & 72 & 86 \\
Hairy nutant & 12 & 0 & 2 & 5 & 11 & 17 & 27 & 37 & 48 & 25 & 55 & 87 \\
Bald erect & 10 & 0 & 1 & 4 & 10 & 16 & 27 & 34 & 43 & 29 & 52 & 74 \\
Bald nutant & 39 & 1 & 2 & 5 & 10 & 16 & 25 & 36 & 49 & 20 & 57 & 81
\end{tabular}

Diff. per cent: hairy erect - hairy nutant $7-$ I 5

$10-$ II $16^{*}$
$13-$ III -2

bald erect - bald nutant $7-$ I 10*

$10-$ II -5

$13-$ III -1

Table 5. The water-retaining capacity of different ear types.

\begin{tabular}{|c|c|c|c|c|c|c|c|c|}
\hline \multirow{4}{*}{ Variety } & \multirow{4}{*}{$\begin{array}{l}\text { Initial } \\
\text { weight }\end{array}$} & \multicolumn{7}{|c|}{ Weight increase per cent of initial weight } \\
\hline & & \multicolumn{2}{|c|}{ 1st day } & \multicolumn{2}{|c|}{ 2nd day } & \multicolumn{2}{|c|}{ 3rd day } & 4th day \\
\hline & & 08.00 & 17.00 & 08.00 & 17.00 & 08.00 & 17.00 & $08.00 \quad 17.00$ \\
\hline & & hours & hours & hours & hours & hours & hours & hours \\
\hline
\end{tabular}

\section{Experiment I}

\begin{tabular}{|c|c|c|c|c|c|c|c|c|c|}
\hline Vakka & 14.7 & 43.9 & 20.6 & 57.6 & 30.9 & 61.3 & 52.2 & - & - \\
\hline b787 & 12.0 & 52.3 & 24.8 & 69.2 & 32.1 & 64.4 & 49.2 & - & - \\
\hline Hairy & 13.4 & 48.2 & 22.7 & 63.4 & 31.5 & 62.9 & 50.7 & - & - \\
\hline Antti & 17.2 & 39.8 & 10.6 & 53.0 & 31.2 & 53.2 & 42.1 & - & - \\
\hline a 8068 & 15.5 & 28.3 & 9.5 & 35.0 & 16.7 & 39.3 & 28.1 & - & - \\
\hline Bald & 16.4 & 34.1 & 10.0 & 44.0 & 23.9 & 46.3 & 35.1 & - & - \\
\hline
\end{tabular}

Diff.

Variety

Type

$\begin{array}{ccc}* & * * & * \\ (*) & * & (*)\end{array}$

$(*)$

(*)

$(*) \quad(*)$

Experiment II

\begin{tabular}{llllllllll} 
Varma & 12.3 & 55.4 & 40.5 & - & 35.8 & 76.2 & 41.8 & 57.8 & 42.5 \\
b787 & 12.8 & 59.8 & 40.7 & - & 42.6 & 79.2 & 50.5 & 55.1 & 46.1 \\
\hline Hairy & 12.6 & 57.6 & 40.6 & - & 39.2 & 77.7 & 46.2 & 56.5 & 44.3 \\
\hline Antti & 17.9 & 39.7 & 20.7 & - & 19.1 & 48.1 & 30.5 & 36.2 & 29.3 \\
a 8068 & 16.0 & 31.4 & 20.0 & - & 20.0 & 45.8 & 25.7 & 36.7 & 28.5 \\
\hline Bald & 16.9 & 35.6 & 20.4 & - & 19.6 & 47.0 & 28.1 & 36.4 & 28.9 \\
\hline
\end{tabular}

Diff.

Variety

Type

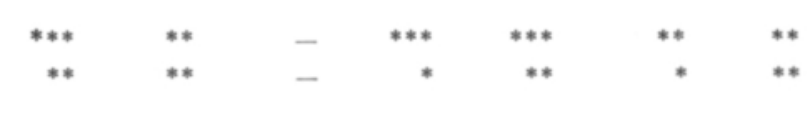


The afternoon weight values indicate the drying rate of hairy and bald ears. The difference in the weight increase between the hairy and bald ears from the initial air-dry weight varied in experiment I from 7.5 to 15.6 per cent and in experiment II from 18.1 to 20.2 per cent, which means in fact that relatively more moisture evaporated from the hairy than from the bald ears. The former were nevertheless always more humid than the latter. Prochaska mentioned that bald glumes dried more rapidly although the absolute weight decrease of hairy glumes was greater than that of bald glumes also in his experiment.

\section{$S u m m$ ary}

In studying the susceptibility of winter wheat to sprouting in the ear attention was paid at the Experimental Farm of the Plant Breeding Institute of Hankkija to the importance of the ear type. This was done by using two methods parallelly: HÄNSEL's sandbed method, which shows the genetic susceptibility of the varieties; and the "nature method" which elicits the effect of ear type. The results led to the following conclusions:

Both methods gave similar results, indicating that the differences in genetic susceptibility to sprouting in the ear (between the varieties) are so great that they emerged by both methods used.

The classification of the material into four groups, hairy erect, hairy nutant, bald erect and bald nutant, showed that the ear type has its own importance as a factor reducing sprouting. The bald ear was found to be better than the hairy and the nutant superior to the erect ear.

The disadvantage of hairy ears is obviously connected with their greater waterretaining capacity. Owing to this they germinate more readily, especially in conditions in which the water capacity of the ears is only occasionally optimal for sprouting as is often the case in the field during the ripening period when the weather keeps changing.

\section{REFERENCES}

(1) Åkerman, A. 1936. Ưber die Keimungsverhältnisse und Auswuchsneigung rot- und weisskörnigen Weizensorten. Der Züchter 8: 25-29.

(2) Belderok, B. 1961. Studies on dormancy in wheat. Academisch proefschrift. 67 p. Wageningen.

(3) Bonnier-Tedin 1940. Biologisk variationsanalys. 325 p. Stockholm.

(4) FeEkes, W. 1938. De neiging tot schot van een zestigtal in Nederland in de practijk verbouwde of in beproeving zijnde tarwerassen. Versl. Techn. Tarwe Comm. XI, p. 211-237. Hoitsema.

(5) Freistedt,_P. 1935. Neue Zielsetzungen in der Gerstenzüchtung. Z. Zücht. A. Pfl.zücht. 20: $169-209$.

(6) Fuchs, W. 1942. Keimungsstudien an Getreide, Z. Pfl.zücht. 24: 165-185.

(7) Heinisch, O. 1937. Der Einfluss des Klimas auf die Dauer der Keimreifung von zweiseiliger Sommergerste. Z. Zücht. A. Pfl.zücht. 21: 451-465. 
(8) HirvolA, S-L. 1962. Tähkäidäntä syksyllä 1962. Koetoim. ja käyt. 19:42-43.

(9) Hutchinson, J., Grees, E. \& Bretr, C. 1948. Resistence of wheat to sprouting in the ear: preliminary investigations. Emp. J. Exp. Agr. 61: 23-32.

(10) HänSEL, H. 1955. Bepoling van de schotresistentie van tarwe door middel van kieming in zand. 5de Cocobro Jaarboekje, p. 31-36.

(11) JokelA, M. 1957. Vehnän ja rukiin tähkissä itäneiden jyvien määrittämisestä. Koetoim. ja käyt. $9-10: 30$.

(12) Kıvı, E. 1957. Ohralajikkeittemme tähkäidännästä. Koetoim. ja käyt. 14: $7-8$.

(13) KuUkankorpi, P. 1958. Kotimaisen rukiin ja vehnän laatu syksyllä 1957. S. Osuustoim. lehti 50: $138-144$.

(14) Nilsson-Ehle, H. 1914. Zur Kenntniss der mit der Keimungsphysiologie des Weizens in Zusammenhang stehenden inneren Faktoren. Z. Pfl. zücht. 2: 153-185.

(15) Ронјаnнermo, O. \& КүцӓмāкI, J. 1960. Tähkäidännästä. Referat: Ưber das Auswachsen des Getreides. Maatal. ja koetoim. 14: 63-82.

(16) Prochaska, M. 1933. Studie über das Auskeimen (๖Auswachsen») verschiedener Weizensorten. Pflanzenbau 9: $91-103,152-160$.

(17) Schleip, H. 1938. Untersuchungen über die Auswuchsfestigkeit bei Weizen. Landw. Jbuch 86: $795-822$.

(18) VAlle, O. 1958. Sääolot ja niiden vaikutus kasvintuotantoomme Etelä-Suomessa $1946-57$. Maatal. ja koetoim. 12: 18-36.

(19) VARIS, E. 1959. Ruislajikkeiden tähkäidäntäherkkyydestä. Summary: The susceptibility of various rye varities to sprouting in the head. Maatal. ja koetoim. 13:117-121.

(20) - 1960. Syysvehnä. Summary: Winter wheat. Siemenjulkaisu 1960: 25-36.

(21) Veijola, T. 1954. Kauppaviljan laatututkimuksia suoritettu 10 vuotta. Maatalous 47: $97-101$.

(22) - - 1960. Vehnän leipoutuvaisuusprobleema. Summary: The problem of the baking properties of wheat. Siemenjulkaisu 1960: 202-213.

(23) Veijola, T. \& Ронјаnhermo, O. 1961. Itäneisyydestä viljan laatutekijänä. Maatalous. 54: 16 - 18.

(24) Wellington, P. S. 1953. A method of assessing premature germination in the ear of wheat. Comptes rendus de l'Association Internationale. D'Essais de Semences 18: 232-238.

(25) Wellington, P. S. \& Durham, V. M. 1958. Varietal differences in the tendency of wheat to sprouting in the ear. Emp. J. Exp. Agr. 26: 47-54.

(26) Voss, J. 1939. Untersuchungen über die Keimruhe und Auswuchsneigung von Getreidesorten. Landw. Jblatt 89: 202-242.

(27) Z ADE, A. 1933. Experimentelle Untersuchungen über die Auswuchsneigung als Sorteneigenschaft des Getreides. Z. Pfl. zücht. 18:212-222.

SELOST U S

\section{TÄHKÄN MORFOLOGISTEN OMINAISUUKSIEN VAIKUTUS SYYSVEHNÄN TÄHKÄ- IDÄNTÄHERKKYYTEEN}

Eero Varis ja Matti Manneri

Hankkijan kasvinjalostuslaitos, Koetila Anttila

Syysvehnän tähkäidäntäherkkyyttä selvitettäessä on Hankkijan koetilalla kiinnitetty huomiota myös tähkätyypin merkitykseen tähkäidäntään vaikuttavana tekijänä. Asiaa selvitettiin käyttämällä rinnan kahta menetelmää: HäNSELin hiekkalaatikkomenetelmää, joka osoittaa lajikkeiden geneettisen herkkyyden, sekä sluonnon menetelmääs, jossa tähkätyypin vaikutus pääsi esille. Tulosten vertailu johti seuraaviin päătelmiin:

Molemmilla menetelmillä saatiin samansuuntaisia tuloksia, mikä osoittaa, että geneettiset (lajik- 
keiden väliset) tähkäidäntäherkkyyserot ovat niin suuria, että ne saadaan selville molemmilla käytetyillä menetelmillä.

Materiaalin jako neljään ryhmään: karvaiset pystyt, karvaiset nuokkuvat, kaljut pystyt ja kaljut nuokkuvat osoitti, että tähkätyypillä on myös oma merkityksensả idäntää edistävänä tai estävänä tekijänä. Kalju todettiin karvaista edullisemmaksi ja nuokkuva pystyä paremmaksi.

Karvaisten tähkien epäedullisuus on ilmeisesti yhteydessä niiden suuremman vedenpidätyskyvyn kanssa. Tästä johtuen ne itävät herkemmin varsinkin olosuhteissa, missä tähkien kosteustila on itämisen kannalta vain ajoittain optimissa, niinkuin pellolla tuleentumisaikana sään vaihdellessa usein sattuu. 